DPSP-88-1183

\title{
REVIEW OF MONITORING WELLS EXHIBTTING ELEVATED pH IN F AND H AREA
}

G. C. Blackmer

JULY 1988

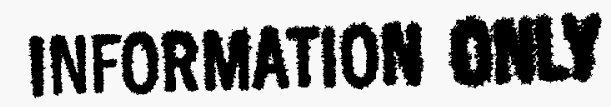

This report was prepared as an account of work sponsored by an agency of the United States Government. Neither the United States Government nor any agency thereof, nor any of their employees, makes any warranty, express or implied, or assumes any legal liability or responsibility for the accuracy, completeness, or usefulness of any information, apparatus, product, or process disclosed, or represents that its use would not infringe privately owned rights. Reference herein to any specific commercial product, process, or service by trade name, trademark, manufacturer, or otherwise does not necessarily constitute or imply its endorsement, recommendation, or favoring by the United States Government or any agency thereof. The views and opinions of authors expressed herein do not necessarily state or reflect those of the United States Government or any agency thereof.

\section{RECEIVED \\ OCT 221998 \\ OSTI}

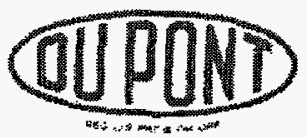

E. I. du Pont de Nemours \& Co.

Savannah River Plant Aiken, SC 29808

PREPARED FOR THE U.S, DERARTMENT OF EVERGV UNOER CONTRACT DE-ACOQ.76SROODO1 


\section{DISCLAIMER}

Portions of this document may be illegible in electronic image products. Images are produced from the best available original document. 
$\operatorname{DPSP}-88-1183$

Revision 0

JuLy 1988

\section{REVIEW OE MONITORING WEIIS EXEIBITING ELEVATED PH IN F AND H AREA}

\section{Introduction}

Several of the monitoring wells instalied at the Savannah River Plart in the past few years exhibit $\mathrm{pH}$ values of 8 or higher. These phis are significantiy higher than average values for the aquifers involved and are also higher than expected for natural waters (Price, 1984). They are also inconsistent with observations in nearby wells. It is therefore suspected that the high phs are not representative of true acuifer conditions.

Two previous studies conducted at SRP (Erice, 1984; Schreeder, 1986) conclude that high pH readings in M-Area monitoring wells and $z$-Area piezometers ate the result of contact between groundwater and grout. Pxice bases his conciusion on water chemistry. Schreeder's evidence is the elationship between pli and amount of water withdrawn from the plezometers- an snitialy high ph drops as more watex is removed. This conclusion is supported by laboratory measurements on water samples collected from cement-bentonite grout which show ph values of 13 (Colangelo and Lytwynshyn, 1987).

This investigation was undertaken to evaluate contamination by grout and drilling fluid as a possible case of elevated pa in montoxing weils at SRP and to develop techniques to rehabilitate the affected wells. FSB and $H S B$ wells were used in this study. Historidal data for weIs wh elevated pH are listed in rable 1 .

\section{Possible cauges of Elevated pH}

The elevated pHs detected in some wells are not typical of natural formation waters and are not consistent with measurements made in nearby wells. There is no pattern to the jocation of the wells which would indicate the possibility of a nigh pr plume. In fact, most of these weils axe located in areas which are characterized by low bH. These facts indicate that high pH measured in the wells is not the result of actul contanination of the groundwater. The other aternative is contamination of certain wells through what Walkez (1983) refers to as "installation traume".

Wells experiencing instalation trauma exhibit anomalous levels of chemical constituents wibn were introduced during well construction. The intensity of the trauma depends on the chemical differences between the natural groundwater and the materlals used for driling Eluid, seals, and backfill. The wells considered in this study were constructed using bentonite in the driling fluid and a cement-bentonite growt. Bentonte contains sodiun and hycroxol ions, and cement contains calcium hydroxide. 证ter which contacts etther one of these substarices will take hydroxol ions into solution, resulting in an inorease in pr of the water. Thus the instaliation 
DESP-88-1.183

Revision 0

July 1988

TABIE 1

Historical data toz FSB and HSB We11s with Elavated pI

\begin{tabular}{|c|c|c|c|}
\hline We11 & $\begin{array}{c}\text { pH } \\
4087\end{array}$ & $\stackrel{\text { PEI }}{2088}$ & $\begin{array}{r}\text { php } \\
2088 \\
\end{array}$ \\
\hline ESBSAC & 10.7 & 9.1 & 10.2 \\
\hline FSB94C & 10.6 & 11.5 & 11.6 \\
\hline ESB956 & 6.7 & 6.8 & 10.7 \\
\hline ESB96A & 11.5 & 21.6 & 11.9 \\
\hline ESB97x & 9.8 & 7.9 & 7.6 \\
\hline 558970 & 11.0 & 10.6 & 10.5 \\
\hline ESB970 & 10.9 & 8.4 & 9.0 \\
\hline ESB98A & 11.2 & $11 . \hat{3}$ & 11.3 \\
\hline$E S B 980$ & 8.1 & 9.1 & 11.4 \\
\hline FSE99A & 8.8 & 7.0 & 9.0 \\
\hline $\mathrm{E} \triangle \mathrm{B} 100 \mathrm{~A}$ & 9.8 & 10.3 & 10.7 \\
\hline ESB101X & 9.4 & 16.9 & $\sim$ \\
\hline ESB120C & 6.9 & 9.6 & 9.6 \\
\hline HSB69A & & & 9.5 \\
\hline HSB8 $4 B$ & & 9.5 & $-m$ \\
\hline HSB84C & & 10.2 & -- \\
\hline HSE85B & & 9.1 & 10.6 \\
\hline HSB101C & & 7.0 & 9.1 \\
\hline HSELOLD & & 9.1 & 9.4 \\
\hline HSB104C & & 8.9 & 9.3 \\
\hline $\operatorname{ESB115C}$ & & 11.4 & 11.2 \\
\hline HSB1 18A & & 8.7 & 7.2 \\
\hline FSB119A & & 9.9 & 9.8 \\
\hline HSB $120 \mathrm{~A}$ & & 8.9 & 9.2 \\
\hline HSBI $21 A$ & & 9.2 & 9.4 \\
\hline HSB $124 A$ & & 11.9 & 11.6 \\
\hline IASE126C & & & 8.2 \\
\hline HSB127C & & & 8.5 \\
\hline HSB1300 & & & 8.4 \\
\hline ASB131C & & & 8.3 \\
\hline HSB1 $33 \mathrm{C}$ & & & 10.3 \\
\hline HSB $135 \mathrm{C}$ & & . & 9.2 \\
\hline$\because \mathrm{SB} 139 \mathrm{~A}$ & & & 9.7 \\
\hline
\end{tabular}


trama in this case will consist of elevated pH and elevated levels of the associated cations, calcium and sodium. The anomalous constituents typlcaliy stabilize over time at nomal levels for the formation. The rate at which stabilization occurs depends on the volume of substances introduced during driiling, the duration of development pumping, and the yieid of the formation. In some cases, stabilization can take one year or more (walker, 1983).

Water which enters a well can contact grout or driling fluid in several ways. If the grout seal around the well casing fractires during curing, or if it shrinks awa from the casing, pathways nay be created for water to percolate down through the grout and move into the screen zone. This is an important consideration because other contaminants from higher horizons may also enter the well in this manner. Water which has contacted the outside of the grout column cen diffuse down from higher in the formation.

Alternatively, the grout itself can penetrate into the filter pack and contact water as it enters the well. This is especially likely to heppen if the grout is placed under excessively high pressure or if the bentonite seal on top of the filter pack is improperiy placed or is not allowed to set for a sufficient length of time. Drilling fluid can remain in the well bore because of improper or insufficient development of the well. It is also possible for drilling fluid to penetrate into the formation. This is likely to happer in highly permeable zones or when high pump pressure forces the fluid out of the borehole.

\section{Characterization of Welis with Elevated and Normal pH}

Assuming that installation trauma is the cause of elevated of in the welis in this investigation, it remains to determine whether grout, ariling fluid, or a combination of these is the prime contributor, and whether there is any pattern which can explain why only certain wells are affected. This will be done by considering a series of parameters including water chemistry, physicai properties of the formation, and installation and samoling factors.

Nater Chemistry: Elevated ph caused by the dissociation of hydroxides in grout and driiling fluid should lead to elevated levels of the associated cations. In the case of contamination by grout, high levels of calcium and possibly of sodium are expected. High leveis of sodium are expected if the cause is drilling fiuid. one way to determine if a particular constituent is present at anomelously high levels is to look at the behavior of the ratio of that constituent to another chemicaliy related species which is not affected by installation trauma (Walker, 1983). This type of analysis was performed on Mg/Ca ratios for wells in $\mathrm{F}$ and $\mathrm{F}$ Areas. For pHs above 10, the Mg/Ca ratios are much lower than those for normal wells. This indicates that calcium content is much higher in the very high ph wells, suggesting contamination by grout. For phs between 3 and $10 . \mathrm{Mg} / \mathrm{Ca}$ ratios vary from lower to higher than nomial welis. This variation suggests that grout has a lesser 
DPSP $-88-1.183$

Revision 0

Tu2y 1988

impact on these wells. In order to tzy to separate the effects of grout and driling fluid, a similax comparison was made for Ca/Na ratio. The presence of sodium in the contaminant plume must be accounted for when consldering wells located in the plume. Ratios were separated by aquifer for purposes of compartson (Table 2).

A wells: Mg/Ca ratios for nomal wells have a small zange. Wells with pH of 9.9 and above have significantly lower ratios, indicating contamination by grout. Wells with pH between 8 and $9.8 \mathrm{have} \mathrm{Mg} / \mathrm{Ca}$ ratios which vary from below to above the normal range, indicating varying infiuence of grout. High pH welis have Iower Ca/Na ratios than normal wells, with one exception. This indicates a higher sodium content and suggests that driling fiud impacted most of these wells, sometimes in combination with grout. Well HSB118A has an anomalously high Ca/Na ratio due to what appears to be an anomalously low Na anaiysis.

C wells: Mg/Ca ratios show stgnificantly more variation than in A welis, which could be cue to the presence of calcareous zones. Wells with $p H$ above 10 have significantly lower ratios, indicating contamination by grout. Welis with pH between 8 and 10 have $\mathrm{Mg} / \mathrm{Ca}$ zatios which vary from below to within the normal range, indicating varying influence of grout. Ca/Na ratios are highly variable due to the combined effects of calcareous zones and the contaminant plume. Wells with high pli have ratios in the same range or higher than normal wells, indicating that grout may have more control than drilling fluid, athough the variability makes this inconclisive.

$D$ welis: Mg/Ca ratios are highly variable. Some of the ESB wells show significant changes in ratios between quarters, possibly indicating a longer stabilization period for water table wells or some problems with anaiyses. The single well with pH over 10 has a significantiy lower Mg/Ce ratio than the normal wells. The other high pH we11s, ES898D and HSB101D, are within the normal range. Ca/Na ratios are also highly variable, probably die to the influence of the contaminant plume. FSB98D is at the low end of the norma: Mg/Ca range and has a high Ca/Na ratio, indicating that grout may be the problem. HSB1010 has a very low Ca/Na ratio, indicating contanination by drilling fluid.

Jennings (1986) reports that one of the effects of driling fluids on groundwater chemistry is an elevated sulfate level. The highest sulfate levels in $\mathrm{F}$ Area and $\mathrm{F}$ Area are in wells with high $\mathrm{pH}$. However, not ail of the high ph wells have high sulfate levels, and there are few weils with normal pH which have high suifate.

Srain Size of Fomation: Grain size can have different effects on the level of pH contamination, depending on the source of contamination. Grout can penetrate coarse-grained material more easily than fine material. According to Dxiscoll (1986), grout 
DPSP-88-1183

Revision 0

Juiy 1988

TABLE 2

Chemical Ratios for Normal and Elevated pH Wells, Separated by Aquifer

Normal pH Wels

Elevated oH Wells

\begin{tabular}{|c|c|c|c|c|c|c|c|c|}
\hline Well & $\mathrm{DH}$ & Molca & Cana & Well & $\mathrm{DH}$ & Molca & CaNa & Source \\
\hline FSB76A & 7.1 & .026 & 8.03 & F\$B96A & 11.5 & .002 & 0.086 & $\mathrm{Ca}, \mathrm{Na}$ \\
\hline FS878A & 3.7 & .029 & 11.74 & FSB97A & 9.8 & .043 & 0.75 & $\mathrm{Na}$ \\
\hline F5879A & 5.6 & .034 & 9.52 & FSB98A & 11.2 & .003 & 1.00 & CaNa \\
\hline \multirow[t]{3}{*}{ FSB87A } & 6.7 & .029 & 11.81 & FSB99A & 8.8 & .05 & 1.12 & $\mathrm{Na}$ \\
\hline & & & & FSBIOOA & 9.8 & .069 & 0.15 & $\mathrm{Na}$ \\
\hline & & & & FSB101A & 9.4 & .032 & 5.69 & $N$ \\
\hline HSB83A & 6.8 & $\cdots$ & 17.25 & HSB69A & 9.5 & $\ldots$ & 3.36 & Na? \\
\hline HSB117A & 7.4 & .028 & 6.83 & HSB118A & 8.7 & .022 & 42.06 & Ca? \\
\hline HSE122A & 7.8 & .024 & 5.84 & HSB119A & 9.9 & .0048 & 1.06 & CaNa \\
\hline \multirow[t]{4}{*}{ HSB123A } & 7.5 & .025 & 5.62 & HSB120A & 8.9 & .015 & 2.89 & $\mathrm{CaNa}$ \\
\hline & & & & HSB121A & 9.2 & .012 & 1.91 & CaNa \\
\hline & & & & HSB $124 A$ & 11.9 & .00082 & 5.04 & $\mathrm{Ca}$ \\
\hline & & & & HSB139A & 9.7 & .098 & 3.15 & $\mathrm{Na}$ \\
\hline $\mathrm{FS876C}$ & 6.1 & .051 & 3.80 & FSB91C & 10.7 & .007 & 0.79 & $\mathrm{Ca}, \mathrm{Na}$ ? \\
\hline FSB78C & 3.9 & .17 & 1.67 & FSBg4C & 10.6 & .002 & 0.18 & $\mathrm{Ca}_{\mathrm{r}} \mathrm{Na}$ ? \\
\hline FSB7SC & 3.4 & .55 & 0.15 & FSB97C & 11.0 & .010 & 0.74 & $\mathrm{Ca}, \mathrm{Na}$ ? \\
\hline FSB87C & 6.7 & .10 & 2.56 & & & & & \\
\hline FSB88C & 5.8 & .082 & 1.25 & & & & & \\
\hline FSB89C & 6.7 & .070 & 0.50 & & & & & \\
\hline FSB90C & 7.1 & .16 & 1.51 & & & & & \\
\hline FSB93C & 6.1 & .22 & 0.69 & & & & & \\
\hline FSB95C & 6.7 & .13 & 1.70 & & & & & \\
\hline FSB98C & 3.5 & .31 & 0.088 & & & & & \\
\hline FSE990 & 6.8 & .19 & 0.45 & & & & & \\
\hline FSB110C & 6.9 & .11 & 0.75 & & & & & \\
\hline HS8103C & 5.2 & .55 & 0.032 & HSB104C & 8.9 & .21 & $\ldots$ & $?$ \\
\hline HS8105C & 6.4 & .091 & 2.25 & HSB115C & 11.4 & .0013 & $\cdots$ & $\mathrm{Ca}$ \\
\hline HSB106C & 6.9 & .11 & 0.75 & HSB126C & 8.2 & .036 & 4.57 & $a$ \\
\hline MSB107C & 6.8 & .076 & 0.65 & HSB127C & 8.5 & .031 & 3.62 & $\mathrm{a}$ \\
\hline HSBIO9C & 7.2 & .050 & 4.24 & HSB130C & 8.4 & .028 & $\ldots$ & $\mathrm{c}$ \\
\hline HSB11OC & 6.0 & .20 & $\ldots$ & HSB $133 \mathrm{C}$ & 10.8 & .0074 & 21.35 & $c$ \\
\hline HSBI11C & 5.6 & .20 & 1.00 & HSB135C & 9.2 & .21 & 4.13 & $?$ \\
\hline HSB112C & 7.2 & .11 & 1.09 & & & & & \\
\hline HSB113C & 6.5 & .17 & 0.82 & & & & & \\
\hline $\mathrm{HSB114C}$ & 4.9 & .46 & 0.15 & & & & & \\
\hline HSB116C & 6.7 & .32 & 0.0086 & & & & & \\
\hline
\end{tabular}



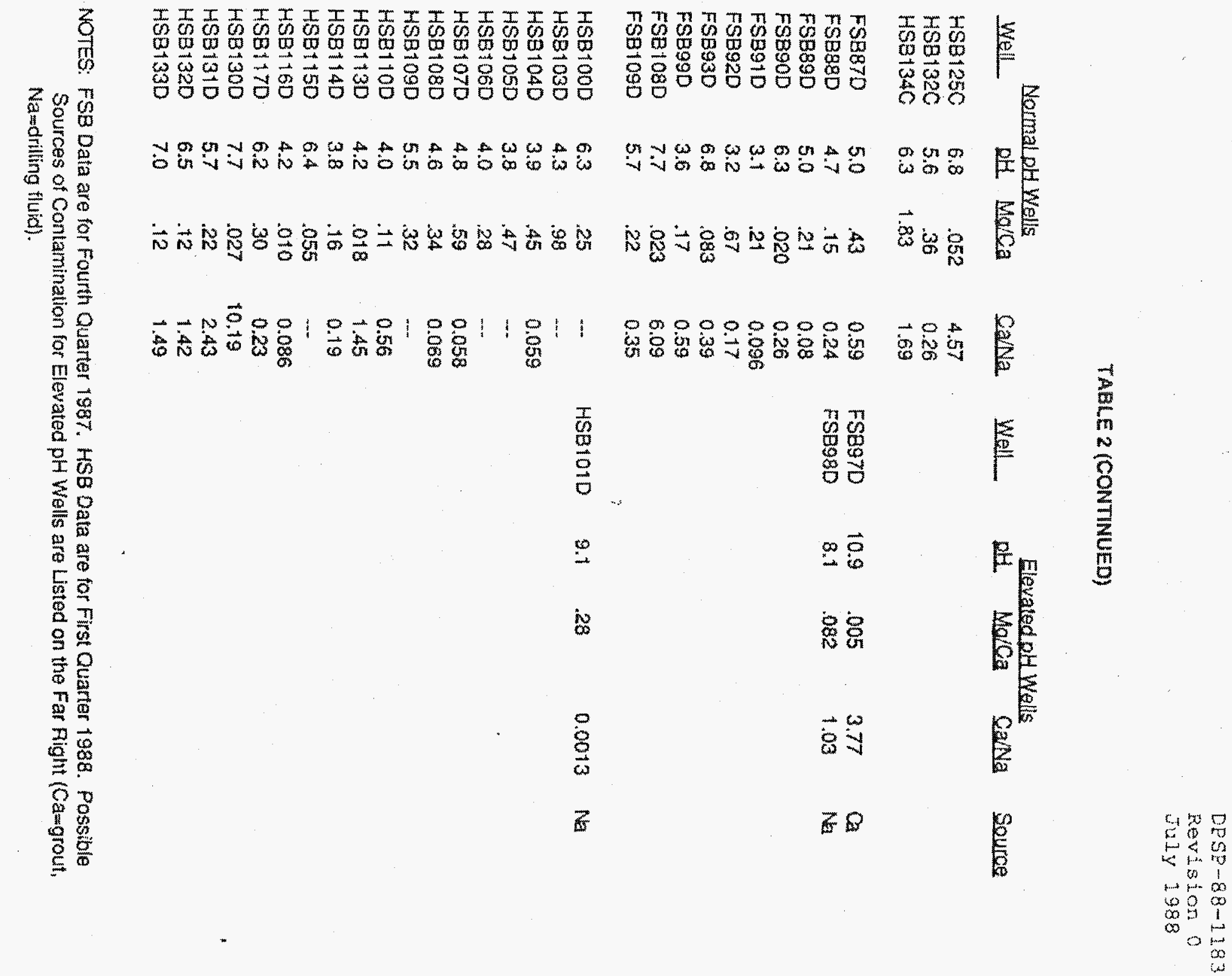
DPSP-B8-1183

Revision 0

July 1988

should not penetrate sand which is finer than $.6 \mathrm{~mm}$. Drilling fluid may penetrate coarse material more easily, but it may be more difficult to remove from fine material.

Inspection of grain-size data from screen zones (taken from well records of welis which had sieve analyses) shows very ittele difference in grain size between normal and high pH wells. All grain sizes are in the fine to medium sand range, except ESBI01A which is coarse sand. The finest grain sizes are found in high pH we11s. Most wells in the 100-140 sieve size range (.0059-.0041 inches) rave been impacted by driliing fluid, bearing out the idea that fluid may remain in fine material.

The grain size of the filter pack may have more influence on grout penetration than the grain size of the formation. The filter packs for the wells under consideration are $.6-.7 \mathrm{~mm}$ or less. This is close to or less than Driscoll's limit for grout penetration. It should therefore be difficult for grout to penetrate the filter pack except under unusual conditions.

Hyciraulic condactivity: Fydraulic conductivity provides a measure of the capacity of the formation to transmit water. The amount of drilling fluid able to penetrate the formation should increase with the hydralic conductivity, so that formations with higher hydraulic conductivity should be more susceptible to high pH. on the other hand, at least a small amount of drilling fluid is likely to penetrate any formation. Low hydralic conductivity could impede the flushing of driling fluid from the screen zone by water moving through the formation, thus prolonging the occurrence of high pa. The majority of the wells with high pH are in the Congaree, which has higher hydraulic conductivity. However, a number of them are in the McBean or water table, which have $a$ significantly lower hydraulic conductivity.

Date of Installation: A large number of FSB and HSB wells were instalied in 1987. All but three of the wells recording elevated $\mathrm{pH}$ were installed at this time. The majority of the wells in this group have nomal pH. There is no separation in time between the installation of wells with elevated pa and wells with normal pH. In other words, the problem cannot be explained by pointing to a group of poorly constructed wells all installed at the same time. It is aiso important to note that these wells have been in place for less than one year.

Well yield: Curxent sampling protocol requires the evacuation of four well volumes of water prior to sampling. However, some wells pump dry before the requisite four volumes are removed (Tables $3 \mathrm{~A}$ ard 3B\}. There are two possible reasons for this. First, the well could be placed in a formation which yleids very littie water. second, grout could be blocking the screen. 
XXIE 3A

\section{Number of Well Volumes Evacuated Bafor Sampling of Ts} We113, Fourth Quartex 1987

\begin{tabular}{|c|c|c|}
\hline 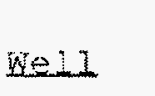 & $\begin{array}{l}\text { We } 1 \\
\text { DE }\end{array}$ & Volumes \\
\hline $\operatorname{ESB} 76$ & 5.6 & 4 \\
\hline FSB76A & 7.1 & 4 \\
\hline FSB $76 \mathrm{~B}$ & 6.6 & 4 \\
\hline$=5 B 76 \mathrm{C}$ & 6.1 & 4 \\
\hline$E 5577$ & 4.0 & 4 \\
\hline ESB78 & 4.0 & 4 \\
\hline ESB?8A & 3.7 & 4 \\
\hline ESB78B & 6.9 & 4 \\
\hline E5578C & 3.9 & 0.5 \\
\hline ESB79 & 3.2 & 4 \\
\hline ESB79 & 5.6 & 4 \\
\hline ESB79B & 6.6 & is \\
\hline ESB? $3 \mathrm{C}$ & $3 \cdot 4$ & 4 \\
\hline ESB87A & 6.7 & 4 \\
\hline ESE87B & 6.4 & 4 \\
\hline ESE87C & 6.7 & 4 \\
\hline$=8888 \mathrm{C}$ & 5.8 & 7 \\
\hline ESB88D & 4.7 & 6 \\
\hline$F \operatorname{sBg} 9 \mathrm{C}$ & 6.7 & 5 \\
\hline ESB89D & 5.0 & 15 \\
\hline FSB90C & 7.1 & 0.9 \\
\hline FSB9OD & 6.3 & 0.5 \\
\hline
\end{tabular}

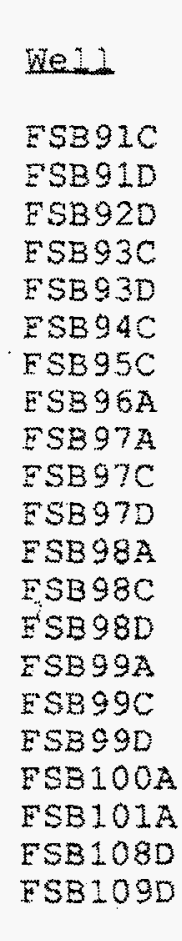

$2 E$

10.7

3.1

3.2

6.1

6.8

10.6

6.7

11.5

9.8

11.0

10.9

11.2

3.5

8.1

8.8

6.8

3.6

9.8

9.4

7.7

5.7

Ne 1

Yo unes

0.7
5
11
5
0.4
0
4
0.7
5
0.7
0.7
7
8
0.4
9
15
12
1
22
0.6
14


FABI, $3 B$

\section{Number of Well Volumes Evacuated Bafora Sampling of HSB Wells, First Quarter 1988}

\begin{tabular}{|c|c|c|c|c|c|}
\hline we 11 & 24 & $\begin{array}{l}\text { Well } \\
\text { yolumes }\end{array}$ & neil & DH & $\begin{array}{c}\text { nel1 } \\
\text { yolines }\end{array}$ \\
\hline HSB65 & 4.5 & 4 & HSB104C & 8.9 & 6 \\
\hline HSB65A & 6.9 & 4 & FSB $104 D$ & 3.9 & 10 \\
\hline HSB 653 & 7.7 & 9 & HSB $105 C$ & 6.4 & 5 \\
\hline HSB 650 & 5.0 & 4 & KSB105D & 3.8 & 7 \\
\hline BSB66 & 5.2 & 5 & MSB106C & 6.9 & 5 \\
\hline HSB 67 & 3.8 & 3 & HSB 1060 & 4.0 & 6 \\
\hline HSB 68 & 3.6 & 4 & HSB107C & 6.8 & 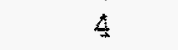 \\
\hline ESB $68 A$ & 6.9 & 4 & HSB107D & 4.8 & 8 \\
\hline ASB $68 \mathrm{~B}$ & 7.3 & 1 & HSB $108 \mathrm{C}$ & 7.2 & 3.5 \\
\hline HSB68C & 6.2 & 1 & HSE $108 D$ & 4.6 & 7 \\
\hline HSB 69 & 3.5 & 4 & HSB109C & 6.7 & 5 \\
\hline HSE7O & 5.0 & 4 & HSB1090 & 5.5 & 8 \\
\hline HSB 71 & 3.6 & 4 & HSB $110 \mathrm{C}$ & 6.0 & 0.7 \\
\hline HSB8 $3 \mathrm{~A}$ & 6.9 & 4 & HSB $12 O D$ & 4.0 & 9 \\
\hline HSB $83 B$ & 5.3 & 4 & "HSB111C & 5.6 & 5 \\
\hline$\because 5 B 83 C$ & 5.2 & 4 & HSB111D & 4.9 & 7 \\
\hline HS583D & 4.8 & 4 & HSBIIIE & 4.2 & 11 \\
\hline HSB $84 A$ & 3.5 & 4 & HSB122C & 7.2 & 6 \\
\hline HSB84B & 9.5 & 4 & $\mathrm{BSB1} 12 \mathrm{D}$ & 5.3 & 10 \\
\hline HSB84C & 10.2 & 0.6 & ASB1 12E & 6.1 & 0.9 \\
\hline HSB84D & 3.8 & 4 & HSB113C & 6.5 & 5 \\
\hline HSEQ5A & 5.9 & 4 & MSB113D & 4.2 & 10 \\
\hline HSB85B & 9.1 & 0.5 & ESB $114 \mathrm{C}$ & 4.9 & 5 \\
\hline ESB850 & 4.9 & 5 & HSB1IAD & 3.8 & 9 \\
\hline HSB8 $6 \mathrm{X}$ & 6.7 & 4 & ESB115C & 11.4 & 0.6 \\
\hline HSB86B & 7.0 & 4 & HSB115D & 6.4 & 3 \\
\hline تSB86C & 4.7 & 4 & $\mathrm{HSB} 116 \mathrm{C}$ & 6.7 & 5 \\
\hline Hs.86D & 3.6 & 6 & HSBII6D & 4.2 & 9 \\
\hline HSBI00C & 5.9 & 5 & HSE118A & 8.7 & 11 \\
\hline KSE10OD & 6.3 & 8 & HSB $119 \mathrm{~A}$ & 9.9 & 8 \\
\hline $15 B 101 C$ & 7.0 & 10 & HSE $120 \mathrm{~A}$ & 8.9 & 11 \\
\hline HSB1010 & 9.1 & 13 & HSQ121A & 9.2 & 4 \\
\hline 1531020 & 6.0 & 7 & HSB $122 A$ & 7.8 & 4 \\
\hline HSS103C & 5.2 & 5 & HSB $123 \mathrm{~A}$ & 7.5 & 5 \\
\hline KS31030 & 4.3 & 7 & ASE $224 \mathrm{~A}$ & 11.9 & 0.8 \\
\hline
\end{tabular}


Seventeen of the nineteen wells which pump dry are screered in the McBean and Barnwell Formations. These formations are predominantly low-permeability clayey sand. The Barnwell Formation also contains sandy clay, silty sand, and sand lenses. Water flow in these formations is inhibited by high clay and silt content. only two wells in the Congaree Eomation pump dry. This formation is predominanty sand and has relatively high pexmeability and good well ylelds. Flow velocity in the Congaree is much bigher.

The $\mathrm{pH}$ of these low-yield weils varies, but a clearer pattern emerges when they are separated by formation. Both nomal and elevated pHs are found in low-yield McBean and Barnwell wells. for the low-yield congaree wells range from 9.8 to 11.9 ; these are within the theoretical range for water in contact with calcium hydroxide.

The data suggest that both mechanisms leading to low yield are represented here. Low permeability and flow velocity are the primery probiems in the Mcsean and Barnweli Formations. This is complicated in less than half of the cases by grout and/or drilling flutd which may block the screen, indicated by elevated pH. on the other hand, low yields in the congaree Formation appear to be caused by grout in the screen zone and not natural properties of the formation. Methods for cleaxing grout and drilling fluid from the screen zone are discussed below. However, if low yield is due to formation properties, there is littie that can be done to improve production without altering natural conditions in the aquifer.

Summary: $\mathrm{Mg} / \mathrm{Ca}$ and Ca/Na ratios show that wells with elevated pH also have elevated leveis of calcium, indicating contamination by grout, and sodium, indicating contamination by driliing fiuid. Several of the sodium levels were inconclusive due to the influence of contaminane plumes. About half of the wells appear to be affected by grout and half by driling fluid, sometimes in comblnation. Any wells with pH of 10 or over appear to be impactec by grout.

We1. 1 considered in this investigation are screened in three different aquiters which exhibit a range of grain sizes and hycraulic conductivities. Elevated $\mathrm{pH}$ is found in all of these aquifers, regardiess of formational properties. However, there are a few trends which can be noted. All welis where 50 of the sample weight had a grain size less than .0059 inches 1100 sievel have elevated pH and appear to be impacted by drilling fluid. Fine grain size could contribute to elevated pH by making removal of driling fluid from the formation more difficult. The grain size of the filter pack is theoretically too small for grout to peretrate. If grout 3 getting into the filter pack, it must be coming in under high pressure or else leaking through an ineffective bentonite seal. Most of the driliznc fluid contamination is found in the $A$ wells which are in a formation with higher hydraulic conductivity. This could be because more drilling Fluid is able to circulate into the formation during drilling. 
Low well yield may be irdiredty related to elevated pH because the materials which cause the pH to rise can also block the well screen. However, low yield can often be attributed to natural properties of the formation.

\section{Recomendations for Further Rction}

\section{Rrevention}

The most bovious way to prevent the problem of elevated pH in monitoring wells is not to use cement grout and not to add bentonite to the drilling fluid. Unfortunately, this is not realiy practical at SRR. Boreholes are subject to collapse without a thickened fluid to hold them open, and the structural support provided by cement grout is necessary. The following construction techniques should help to alleviate the problem.

- Vse as ltttle bentonite as possible in the drilling filuid. This will leave a thinner filter cake, which has a better chance of complete removal during development.

- Minimize the time that fluid sits in the mud pit without circulating. When bentonjte sits still, it becomes stiffer, and the increased pump pressure requixed to resume circulation could force the fluid into the formation (Driscoll, 1986)

- Develop the well as soon as possible after installation to improve the probability of complete removal of driling Eluid.

- Extend the time of development.

- Extend the filter pack for at least two feet above the screen (Colangelo, 1988), 1. the stratigraphy allows. This increases the potential for dilution of hydroxol-rich solutions percolating through the grout column, thus lowering the phi of these waters before they reach the screen zone.

- Use a thicker bentonite seal to increase the probability of an " effective seal. Coiangelo (1988) recommends a minimum of 5 feet of bentonite pellets.

- Alow a longer hydration time for the bentonite seal. Colangelo (1988) recommends a minimum hydration time of 6 hours. Other sources suggest a hydration time of 24 hours. Under conditions at SRP, a long hydration time may not be practical. The added hours can significantly increase the cost of instaling a well. There is also the possibility that the hole may cave if it is lett standing for a long time.

- Use the proper mix of cement, bentonite, and water in the grout to insure a good seal without shxinking, Eracturing, or excess water. Colangelo (1988) suggests a mix of 94 pounds of portland cement, 5 pounds of bentonite, and 6 to 8 galions of water. The amount of 
DESP $-88-1183$

Revision 0

Tuly 2988

water should be minimized because free water not used in hycrolysis will contain hydroxol ions (Colangelo, 1988). At the same time, the grout cannot be too thisk or the pressure required to pump it could force it through the bentonite seal and into the filter pack.

\section{Rehabilitation}

Investigations into installation trauma by walker (1983) indicate that most wells recover on their own over a pexiod of several months to several years. Six M-Azea well clusters $(47,49,51,52,53,54)$ installed in october, 1987 illustrate this phenomenon, Stabilization measurements made following ingtallation show that out of 14 we $11 \mathrm{~s}$, six had pH over 8 (Horvath, 1987). All of the wells except MSB523 stabilized at nomal values. RH measurements from the first quarter of 1988 show that all of these wells except MSB52B and $54 \mathrm{C}$ now have nomal pH. First quarter pHs are lower than final stabilization pHs in nine of the 14 weils.

When welis do not recover quickiy on their own, it is desirable to accelerate the natural rehabilitation process. One way to do this is to pump the affected wells for an extended period of time. Previous onsite studies (Schreeder, 1986; Horvath, 1987; Janssen and 01son, 1987) show that pH drops as more water is removed from a well. In these tests, the welis were pumped for extended periods with pH measurements taken at intervals. Pumping continued until $\mathrm{pH}$ stabilized. In most cases, pH dropped to normal levels for formation water. However, no follow-up measurements were made to determine whether the drop in pH was a short-term effect or actual rehabilitation. Two rehabilitation techriques axe outinned below.

1. Pump the well until pH stabilizes, taking pH measurements at intervals of one well volume. After pumping stops, allow the well to recharge and measure the pH. If the pH does not rise again, the weli ss rehabilitated. If the pH returns to ar unacceptably high level, then the process should be repeated. As long as the peak pH is lower than the previous peak, continue the pumping-recharge-pumping process until the well stabilizes. If the peak ph does not drop, but the well stabilizes at a normal value after pumping, the well will just have to be pumped every time it is sampled. If the pH never drops to normal, try another metrod.

Analyses for calcium, sodium, and sulfate can be done in conjunction with the pumping process in order to better define the relationships of these constituents to elevated pH. Behavior of these constituents relative to $\mathrm{pH}$ level can be characterized by sampling at initial water, low pr point, and post-recharge nigh pH point.

2. Redevelopment may help lower the pH, especially in cases where residual drilling fiuid is a suspected cause of contamination. Take a sample following normal procedures tremoving four well volumes), and measure the pH. Redevelop the well. Sample agair 
according to normal procecures. If the pH is nomal, no further action is necessary. If the pH is still elevated, try the pumping process described above.

3. If the pu cannot be lowered, the well should be replaced. Replacement should be a last resort as there is no guarantee thet the new well will not have the same problem.

The pumping method of rehabilitation was used on well ESBlo1A over a five day period from June 23 to June 27,1988 (mable 4). on June 23 , the pH staxted at 8.99 atter pumping 30 galions and cropped to 7.11 after pumping 1110 gallons. The wel was allowed to recharge overnight. On June 24 , the pH started at 7.85 after pumping 30 gailons and dropped to 7.25 after pumping 550 gallons. The weli was then allowed to stand for two days. On June 27 , the pH started at 7.19 after pumping 50 gallons and dropped to 6.69 after pumping 200 gallons. Each time the well recharged, the peak pit was lower; each time it was pumped, it reached a lower value. This well responded positively to repeated extencer pumping. Euture pi measurements will determine whether the well is truly rehabilitated.

The effectiveness of these methods in rehabilitating wells has not been fully tested. Some trial-and-error experimentation in the field will be necessary to determine the best procedure. It is possible that some combination of pumping and redeveloping may be most effective in reducing $\mathrm{pH}$. 
TABTE 4

Results of Extended Funping Remediation on FSB101

Gall
Eunp
30
50
90
100
130
150
170
190
200
230
250
300
510
550
1210

$6 / 23 / 88$

2 晦 cond

$6 / 27 / 88$

unped

8.99160

7.85140

8.68160

$7,42 \quad 140$

8.30150

$7.35 \quad 130$

8.08140

$7.87 \quad 150$

7.36

7.82150

7.33

DE

cond.

$7.83 \quad 150$

$7.63 \quad 150$

$7.24 \quad 140$

$7.21 \quad 130$
7.19 .160
6.96150
$6.60 \quad 150$
$6.69 \quad 160$

1110

130




\section{References}

Colangelo, R. V., 1988, "Thert Annular Space Materials, the Acid Test," Ground Water Monitoring Reviow, Vol. 8, No. 2, p. $57-58$.

Colangelo, R. V. and $G$. R. Lytwyryshyn, 1987. Cement Bantonite Grout and its Effect on water quality Samples: a Field Test of Volclay Grout, in Proceedings, Eirst National Outdoor Action Conference on Aquifer Restoration, Ground Water Monitoring and Geophysical Methods, May 18-21, Las Vegas, Nevada, NWWA.

Driscoll, F. G., 1986. Groundwater and Wells, and ed., Johnson Division, St. Paul, Minnesota, 1108 pages.

Gibi, J. P., 1986. How Drilling Fluids and Grouting Matazials Affect the Integrity of Ground hatex Samples from Monitoring Wells, in Eroceedings, Sixth National Symposium and Exposition on Aquifer Restoration and Ground Water Monitoring, May 19-22, onio state university, NWWA.

Horvath, J. G., 2987 . Elevated pH in Phase IIB Wells in the $A / M$ hrea, Inter-Office Memorandum, $E$. $I$. du Eont de Nemours and Company, Savannah River Plant, Aiken, SC.

Janssen, $I . I$. and $C$. M. Olson, 1987. Quality Assurance of Recently Installed wells by Testing Chemical Parameters, Inter-office Memorandum, E. I. du Pont de Nemours and Company, Savanmah River Laboratory, Aiken, SC.

Jennings, K. V, B., 1986. The Effect of Grouta, Salants, and Drilling Fluids on the Quality of Ground-Water Sanples, in Proceedings, Sixth National Symposium and Exposition on Aguifer Restoration and Ground water Monitoring, May 19-22, ohio State University, NWA.

Price, $V$, 1984. High $p F$ in Wolls May Indicate Loakdgo between casing and Grout, D2ST-84-923, E. I. du Pont de Nemours and Company, Savannah River Laboratory, Aiken, sc.

Schreeder, W. B., 1986. Relationship between pH and Groundwatex Withdrawal in $z$ Mrea Pianomator, DPST-86-528, E. I. du Pont de Nemours and Company, Savannah River Laboratory, Aiken, sc.

Walker, S. E., 1983. Background Ground-Water Quality Monitoring: Well Installation Traum, in Proceedings, Third National Symposium on Aquifer Restoration and Ground-Watez Monitoring, worthingtor, ohio, NWWA. 